\title{
SISTEM PAKAR PEMBAGIAN HAK WARIS BERDASARKAN HUKUM ISLAM BERBASIS ANDROID DENGAN METODE FORWARD CHAINING
}

\author{
(ANDROID-BASED EXPERT SYSTEM FOR SHARING OF INTEGRITY BASED ON ISLAMIC LAW \\ WITH FORWARD CHAINING METHOD)
}

\author{
Ahmad Fathoni)' ${ }^{1}$, Muhammad Zainuddin'2, Marwan Hakim ${ }^{3)}$ \\ ${ }^{1,2,3)}$ Program Studi Teknik Informatika, STMIK Syaikh Zainuddin NW Anjani \\ Jalan Raya Mataram- Lb. Lombok, KM 49 Anjani, Suralaga, Lombok Timur-NTB, Indonesia \\ e-mail: $\underline{\text { fathoni338@stmiksznw.ac.id }}{ }^{1)}$, muzain123@gmail.com ${ }^{2)}$,ten2one7@yahoo.co.id ${ }^{3)}$
}

\begin{abstract}
ABSTRAK
Indonesia merupakan salah satu Negara dengan jumlah penduduk terbesar didunia. Hampir $85 \%$ dari jumlah penduduk Indonesia adalah umat beragama Islam. Salah satu permasalahan yang dihadapi sebagian besar penduduk Indonesia khususnya yang beragama islam adalah permasalahan pembagian hak waris. Banyak orang islam yang tidak menggunakan lagi sistem pembagian waris menurut syaria'at islam dikarenakan kurangnya ahli ilmu waris dan kurangnya pengetahuan tentang pembagian hak waris menurut islam sehingga persoalan waris sering sekali menjadi pemicu pertikaian yang menimbulkan keratakan hubungan kelurga. Disisi lain saat ini teknologi yang sedang berkembang pesat adalah teknologi Android. Hampir setiap orang memiliki handphone yang berbasis Android. Android sendiri adalah suatu sistem operasi yang berjalan pada smatphone dan menyesuaikan spesifikasi dari kelas low-end hingga highend. Hampir semua vendor saat ini mengembangkan produknya dengan sistem operasi Android karena peminatnya yang semakin meningkat tajam. Berdasarkan permasalahan dan kondisi diatas maka dibuatlah sebuah aplikasi sistem pakar pembagian harta warisan berdasarkan hukum islam berbasis Android dengan metode forward chaining, yang dapat membantu menyelesaikan permasalahan yang dihadapi masyarakat di atas.
\end{abstract}

Kata Kunci: Android, Sistem Pakar, Hak Waris, Forward Chaining.

\begin{abstract}
Indonesia is one of the countries with the largest population in the world. Nearly $85 \%$ of Indonesia's population is Muslim. One of the problems faced by the majority of the Indonesian population, especially those who are Muslim, is the problem of the distribution of inheritance rights. Many Muslims no longer use the inheritance distribution system according to Islamic Shari'a due to the lack of heirs and lack of knowledge about the distribution of inheritance rights according to Islam so that inheritance issues are often a trigger for disputes that lead to flattening family relations. On the other hand, currently the technology that is developing rapidly is Android technology. Almost everyone has an Android-based mobile phone. Android itself is an operating system that runs on smartphones and adjusts specifications from low-end to high-end classes. Almost all vendors are currently developing their products with the Android operating system because the demand is increasing sharply. Based on the problems and conditions above, an expert system application for the distribution of inheritance based on Islamic law based on Android was made with the forward chaining method, which can help solve the problems faced by the community above.
\end{abstract}

Keywords: Android, Expert System, Inheritance, Forward Chaining

\section{Pendahuluan}

$\mathrm{S}$ istem pakar merupakan salah satu cabang kecerdasan buatan yang mempelajari bagaimana meniru cara berpikir seorang pakar dalam menyelesaikan suatu permasalahan, membuat keputusan maupun mengambil kesimpulan sejumlah fakta. Kajian pokok dalam sistem pakar adalah bagaimana mentransfer pengetahuan yang dimiliki oleh seorang pakar ke dalam komputer, dan bagaimana membuat keputusan atau mengambil kesimpulan berdasarkan pengetahuan itu. Dengan menyimpan informasi dan digabungkan dengan himpunan aturan penalaran yang memadai memungkinkan komputer memberikan kesimpulan atau mengambil keputusan seperti seorang pakar. 
Perkembangan teknologi saat ini telah memberikan pengaruh yang sangat besar bagi dunia informasi. Seiring dengan tingkat mobilitas yang tinggi, beberapa tahun terakhir marak perangkat bergerak atau mobile device. Salah satu perangkat mobile yang paling pesat adalah Handphone dimana hampir setiap orang memilikinya. Handphone yang sedianya sebagai alat komunikasi, saat ini sudah lebih dari fungsi dasarnya. Berbagai macam fitur telah ditanamkan, seperti pengolah gambar dan video, pengolah dokumen dan lain sebagainya. Hal ini tidak lepas dari penggunaan Sistem Operasi pada Handphone. Layaknya pada komputer, Handphone pun dapat di instal berbagai macam aplikasi yang diinginkan.

Android merupakan Sistem Operasi mobile yang tumbuh di tengah Sistem Operasi lainnya yang berkembang dewasa ini. Sistem Operasi lainya seperti Windows Mobile, i-Phone OS, Symbian. Android sebagai Sistem Operasi bergantung pada versi Linux 2.6 untuk layanan sistem inti, dapat digunakan di berbagai perangkat mobile. Android memiliki tujuan utama untuk memajukan inovasi piranti mobile agar pengguna mampu mengeksplorasi kemampuan dan menambah pengalaman lebih dibandingkan dengan platform mobile lainnya. Hingga saat ini Android terus berkembang, baik dari sisi sistem maupun aplikasinya. Banyak aplikasi Android yang dapat mendukung atau mempermudah dalam suatu pekerjaan. Aplikasi Pembagian Hak Waris berdasarkan Hukum Islam tentu diharapkan dapat mendukung atau mempermudah dalam pembagian harta warisan.

Pada masyarakat sekarang, banyak orang Islam yang tidak lagi menggunakan sistem pembagian waris menurut syari'at Islam. Padahal hal itu bertentangan sekali dengan Al-Qur'an sebagai kitab suci umat Islam itu sendiri. Dengan jelas diungkapkan dalam Al-Qur'an: (dalam Irfan Habiburrahman, 2008).

\section{Artinya :}

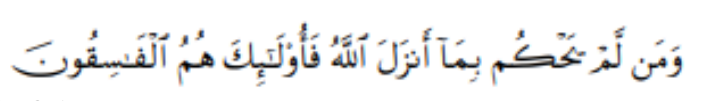

"Barang siapa tidak memutuskan perkara menurut apa yang diturunkan Allah (Alqur'an), maka mereka itu adalah orang-orang yang fasik" (QS Al Maidah : 47).

Banyak sekali alasan mengapa orang Islam enggan atau malas untuk membagikan harta waris mereka dengan cara yang telah diatur oleh syari'at Islam diantaranya :

1. Kebanyakan Orang Islam tidak memahami bagaimana cara pembagian harta waris menurut syari'at Islam.

2. Cara pembagian harta waris menurut syari'at Islam yang cukup rumit.

3. Jarangnya para ahli ilmu faraidh (waris).

Pembagian warisan sering kali menjadi suatu permasalahan yang terkadang memicu pertikaian dan menimbulkan keretakan hubungan keluarga. Penyebab utamanya adalah keserakahan atau ketamakan manusia, dan juga karena kurangnya pengetahuan pihak-pihak yang terkait tentang hukum pembagian warisan. Di samping itu terbatasnya pakar atau orang-orang yang memiliki pengetahuan dan keahlian khusus yang dapat memberikan solusi terhadap orang-orang yang membutuhkan informasi tentang pembagian harta warisan secara Islam. Pada prinsipnya pembagian warisan dalam hukum Islam bukan untuk menyulitkan manusia, tetapi untuk memberikan kemudahan bagi manusia dan agar tidak terjadi pertengkaran dalam keluarga setelah Almarhum meninggal. Ilmu faraid (waris) memberikan penjelasan tentang cara-cara pembagian harta waris, seperti siapa saja yang berhak mendapat harta waris dari semua ahli waris dan berapa jumlah bagiannya.

Hukum kewarisan dalam Islam mendapat perhatian yang besar karena pembagian warisan sering menimbulkan akibat-akibat yang tidak menguntungkan bagi keluarga yang ditinggal mati. Warisan adalah soal apa dan bagaimana berbagai hak-hak dan kewajiban-kewajiban tentang kekayaan seseorang pada waktu ia meninggal akan beralih kepada keluarga yang masih hidup. Berdasarkan penelusuran yang dilakukan hukum online, kewarisan menempati posisi nomor dua buku tahunan Yurisprudensi Mahkamah Agung (MA) hampir setiap edisi terbitan dari tahun pertahun mengutip putusan perkara waris. Hal tersebut menunjukan pentingnya masalah waris mendapat perhatian. Hukum kewarisan Islam pada dasarnya berlaku untuk umat Islam dimana saja di dunia ini (Setyawan, 2016).

Pembagian harta warisan sebagian umat Islam masih berpedoman kepada kitab fikih yang berasal dari madzhab yang berbeda-beda, hal ini sering menimbulkan putusan yang berbeda-beda, 
walaupun perkara-perkara yang diajukan kepadanya sama. Agar perbedaan perbedaan itu tidak muncul, maka seyogianya pembagian Harta Warisan menggunakan acuan Kompilasi Hukum Islam (HKI) diseluruh Instansi Pengadilan Agama, karena KHI sudah ada dasar hukumnya dengan dikeluarnya Instruksi Presiden No 1 Tahun 1991 dengan kesepakatan ulama di Indonesia kepada Menteri Agama untuk menyebarluaskan KHI ini kepada masyarakat.

Berdasarkan data yang peroleh dari Pengadilan Agama Banjarmasin Kelas 1A, bahwa jumlah kasus sengketa waris selama beberapa tahun terakhir yaitu pada tahun 2016 sebanyak 168, tahun 2017 sebanyak 125 dan tahun 2018 sebanyak 108 atau rata-rata pertahun mencapai 134 kasus. Selanjutnya hasil angket yang dikumpulkan dalam penggalian permasalahan, dari 20 orang responden (masyarakat) secara acak menunjukkan bahwa $90 \%$ masyarakat tidak pernah mendengar/mengetahui tentang pembagian harta warisan berdasarkan KHI, 100\% masyarakat tidak mengetahui secara detail perbedaan prinsip antara harta warisan berdasarkan Fiqih Islam dengan KHI.

Dalam penelitian ini, penulis ingin menyajikan pengadopsian cara berpikir manusia (dalam hal ini para pakar ilmu faraidh (ilmu waris)) berdasarkan Hukum Islam ke dalam suatu program "Sistem Pakar Pembagian Hak Waris berdasarkan Hukum Islam Berbasis Android".

Dengan latar belakang tersebut di atas, diharapkan program ini dapat bermanfaat bagi masyarakat luas, khususnya umat Islam dalam pembagian Harta waris yang sesuai dengan syari'at Islam sebagaimana dijelaskan dalam Al-Qur'an dan AlHad

\section{STUDI PUSTAKA}

Adapun penelitian yang serupa dengan Sistem Pakar Pembagian Hak Waris Berdasarkan Hukum Islam adalah sebagai berikut :

Penelitian yang dilakukan oleh Nirsal, yang berjudul "Sistem Informasi Pengelolaan Data Pembagian Harta Warisan Menurut Hukum Islam pada Pengadilan Agama Kota Palopo" menyimpulkan bahwa Sistem Informasi pengolahan data ini diharapkan dapat membantu setiap orang yang membutuhkan nilai pembagian harta waris dengan menggunakan cara pembagian yang berdasarkan hukum Islam. Nilai harta waris yang akan dibagi adalah harta waris setelah dikurangi wasiat pewaris bila ada wasiat, hutang piutang dan biaya pengurusan jenazah. Hasil pembagian adalah berupa nilai prosentase untuk setiap ahli waris yang berhak mendapatkan harta waris setelah proses pembagian. Penentuan nilai nominal harta waris tidak akan dihitung dalam sistem ini. Hasil yang diperoleh dari sistem penunjang keputusan ini adalah output berupa informasi golongan ahli waris yang berhak mendapatkan harta waris, dan nilai prosentase pendapat waris untuk masing-masing ahli waris yang berhak mendapatkan harta waris.

Selanjutnya Penelitian yang dilakukan oleh Didin Samsudin Adhuri dan Abdul Aziz, yang berjudul "Aplikasi Sistem Pendukung Keputusan Perhitungan Waris Berbasis Web" menyimpulkan bahwa dalam hukum waris yang diatur adalah persoalan bagaimana harta peninggalan harus diperlakukan, kepada siapa saja harta itu dipindahkan dan bagaimana cara perpindahan harta peninggalan tersebut. Untuk membantu pengguna didalam mengetahui bagian dan menghitung harta waris, maka dikembangkan sebuah perangkat lunak yang mampu membantu pengguna untuk mengetahui bagian-bagian berapakah yang akan diterima oleh ahli waris. Pengembangan perangkat lunak tersebut menggunakan metode Rational Unified Process (RUP), dengan bahasa permodelan Unified Modeling Language (UML). Pada tahap implementasi digunakan perangkat pemrograman berbasis web, PHP MySQL. Pengujian terhadap perangkat lunak dilakukan dengan metode forward chaining. Perangkat lunak yang dihasilkan mampu membantu pengguna dalam hal penghitungan faroidh.

Berikutnya penelitian yang dilakukan oleh Tiara Lisya Ardhilla dan Novrina, yang berjudul "Aplikasi Sistem Pakar Ilmu Faraidh Berbasis Web Menggunakan Metode Forward Chaining" menyimpulkan bahwa penelitian ini dibuat pengadopsian cara berpikir manusia (dalam hal ini para pakar ilmu faraidh (ilmu waris)) ke dalam suatu program sistem pakar waris berbasis web dengan menambahkan proposi untuk permasalahan au'l dan rad dengan disertakan fitur potongan ayal Al-Qur'an atau Al-Hadits, kamus istilah ilmu faraidh dan forum diskusi untuk user bisa bertukar pikiran perihal ilmu faraidh. Website ini diharapkan dapat mempermudah orang awam mempraktikan pembagian waris sesuai dengan 
sumber hukum faraidh tanpa harus menguasai ilmu perhitungan faraidh.

Selanjutnya penelitian yang dilakukan oleh Fikri Fahru Roji, Eri Satria, dan Dewi Tresnawati yang berjudul "Pengembangan Aplikasi Pembagian Harta Waris Islam Berbasis Android" menyimpulakan bahwa dengan menerapkan basis Android pada aplikasi pembagian waris islam, aplikasi bisa digunakan dimanapun dan kapanpun tanpa memerlukan koneksi internet. Dalam proses pengembangan aplikasi pembagian waris Islam dengan menggunakan metode rekayasa perangkat lunak multimedia versi LutherSutopo menjadikan aplikasi yang dibangun lebih interaktif dengan hasil akhirnya sesuai dengan ide/konsep awal.

Berikutnya penelitian sejenis juga pernah dilakukan oleh Ridwan Setiawan, Dini Destiani, dan Cepy Slamet (2012), mereka melakukan penelitian perancangan sistem pakar untuk pembagian waris menurut hukum Islam berbasiskan web. Aplikasi web sistem pakar ini berfungsi sebagai referensi dalam menentukan proporsi pembagian waris menurut syariat Islam sesuai dengan kasus yang ada, dan menyajikan informasi seputar ilmu waris Islam. Pencarian solusi menggunakan metode forward chaining cocok untuk menyelesaikan permasalahan yang mempunyai tingkatan prioritas pada rule yang dibangun pada basis pengetahuan.

6. Kemudian penelitian yang dilakukan oleh Herlin Puspita yang berjudul "Aplikasi Pembagian Warisan Menurut Kitab UndangUndang Hukum Perdata (Hukum Wariris Barat)' menyimpulkan bahwa program aplikasi pembagian harta warisan menurut Kitab Undang Undang Hukum Perdata dirancang dengan perhitungan yang sesuai dengan perundangundangan yang berlaku (Kitab Undang-Undang Hukum Perdata) yang diperuntukkan bagi orang non muslim saja, dan tidak diperuntukkan untuk orang muslim sesuai dengan perundangundangan yang berlaku di Indonesia. Aplikasi yang dibuat dengan Pemrograman Visual Basic 6.0 ini mampu memberikan kemudahan terhadap pembagian harta warisan yang sesuai dengan perundangundangan yang berlaku.

Berdasarkan beberapa penelitian terdahulu yang dikemukakan, aplikasi pembagian harta warisan yang dibuat hanya menjelaskan bagaimana proses pembagian harta warisan dan berapa besar bagian masing-masing pihak yang akan diperoleh ahli waris berdasarkan permasalahan yang ada berdasarkan Fiqih Islam. Sedangkan, pada penelitian yang penulis lakukan ini adalah membuat model Aplikasi pembagian hak warir berdasarkan Hukum Islam sesuai dengan KHI yang merupakan hukum yang sudah ditindak lanjuti dengan keluarnya Intruksi Presiden No 1 Tahun 1991 dan telah disepakati oleh majelis ulama Indonesia kepada Menteri Agama.

\section{METODE PENELITIAN}

\section{A. Jenis Metode Penelitian}

Dalam penelitian ini, penulis melakukan penelitian dengan menggunakan metode penelitian kualitatif deskriptif. Metode penelitian kualitatif deskriptif adalah metode penelitin yang berlandaskan pada filsafat postpositivisme atau enterpretetif, digunakan untuk meneliti kondisi obyek yang alamiah, dimana peneliti adalah instrumen kunci, teknik pengumpulan data dilakukan secara triangulasi (gabungan observasi, wawancara, dokumentasi), data yang diperoleh cenderung kualitatif, analisis data bersifat induktif/kualitatif, dan hasil penelitian bersifat untuk memahami makna, memahami keunikan, mengkonstruksi fenomena, dan menemukan hipotesis (Sugiyono, 2017:9).

\section{B. Metode Forward Chaining}

Metode forward chaining merupakan metode pencarian yang dalam prosesnya memulai dari data fakta-fakta yang ada, dari data yang ada tersebut dicari suatu solusi dari masalah yang sedang dihadapi. Metode ini memulai proses pencarian dengan data seehingga ini juga disebut juga data-driven. Cara kerja dari metode forward chaining adalah Inference engine atau mesin inferensi memilih rule-rule yang tersedia dimana bagian premisnya yang sesuai dengan informasi yang ada pada bagian working memory (Riskadewi dan Hendrik, 2005).

\section{HASIL DAN PEMBAHASAN}

Setelah melaksanakan setiap tahapan dalam prosedur kerja yang telah dijelaskan, maka telah dihasilkan sebuah aplikasi media bantu berbasis android dalam perhitungan waris sesuai syariat islam. 


\section{1) Splass Screen}

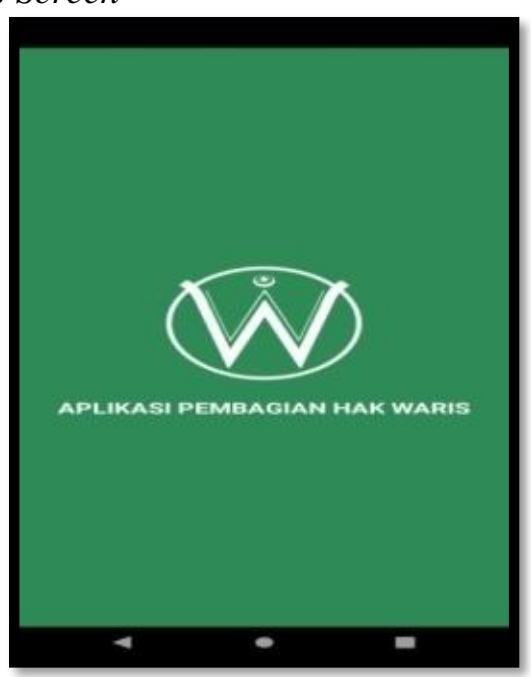

Gambar 1Tampilan Splass Screen

Tampilan Splass Screen ini merupakan tampilan awal begitu aplikasi baru dibuka. Tampilan ini akan muncul hanya dalam 3 detik dan akan langsung menuju tampilan Menu Home.

\section{2) Мепи Home}

Aplikasi ini memiliki tampilan home sebagai tampilan utama dan tampilan isi dari tiap menu menu yang ada didalam tampilan home.

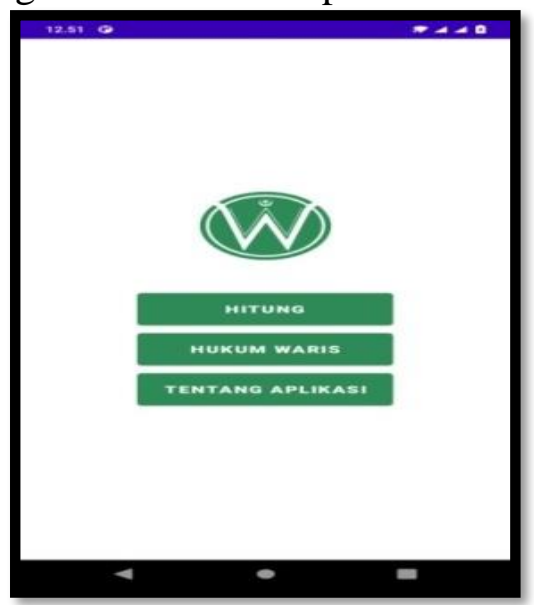

Gambar 2. Tampilan Menu Home

Tampilan home ini merupakan tampilan yang berisi tombol-tombol yang terhubung ke dalam tampilan menu yang berkaitan dengan faraidh. Dalam tampilan ini terdapat tombol menu Hitung, , tombol menu Hukum Waris dan tombol menu Tentang Aplikasi.

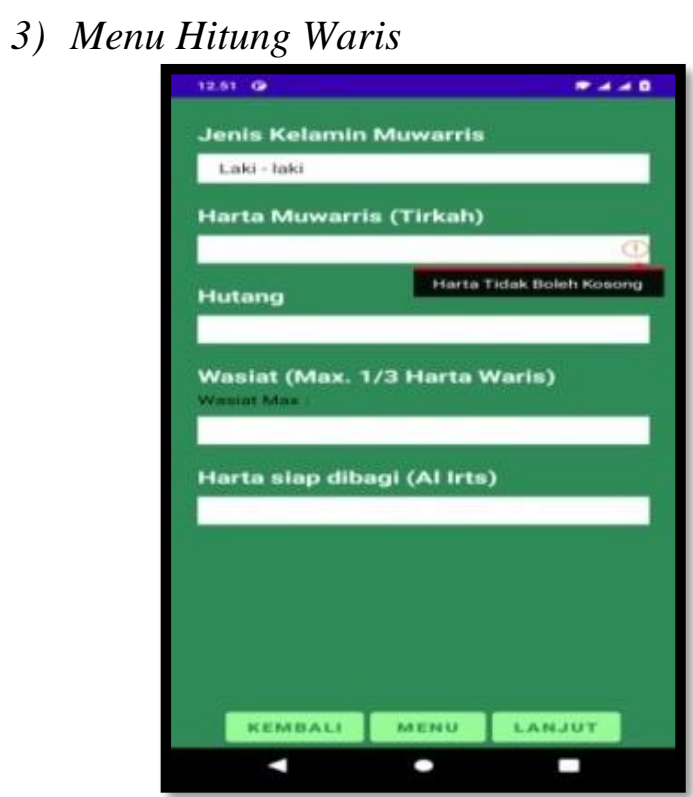

Gambar 3. Tampilan Hitung Waris

Dalam tampilan menu hitung waris pertama kali layar kan menampilkan pertanyaan jumlah harta yang ditinggalkan mayit, hutang, wasiat (maksimal 1/3 dari harta mayit). Disini pengguna dapat memasukkan angka tentang banyaknya jumlah harta yang ditinggalkan mayit tersebut pada kolom harta muwarrist.

\section{4) Tampilan Jumlah Ahli Waris}

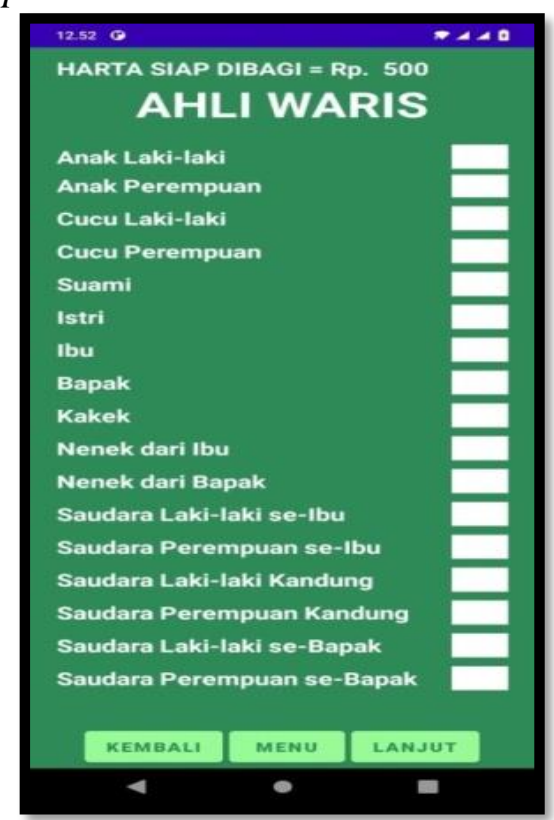

Gambar 4. Tampilan jumlah ahli waris

Pada tampilan ini terdapat nama-nama ahli waris yang tersedia mulai anak, cucu, orang tua, kakek nenek, suami, istri, hingga saudara baik saudara kandung, saudara seibu maupun saudara sebapak. Nilai awal untuk jumlah ahli waris 
adalah nol. Pengguna dapat merubah nilai tersebut sesuai dengan kondisi jumlah ahli waris yang ada.

\section{5) Menu Hasil Hitung Waris}

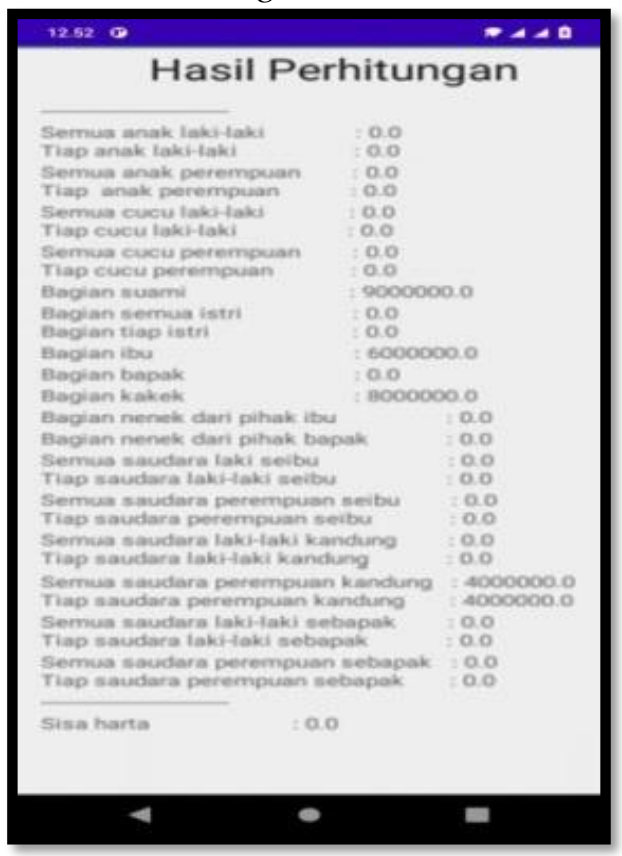

Gambar 5. Tampilan hasil perhitungan

Pada menu ini akan ditampilkan hasil perhitungan dari pembagian waris. Menu ini ditampilkan setelah pengguna memasukkan jumlah harta yang ditinggalkan mayit dan banyaknya ahli waris yang dimiliki mayit.

\section{6) Menu Hukum Waris}
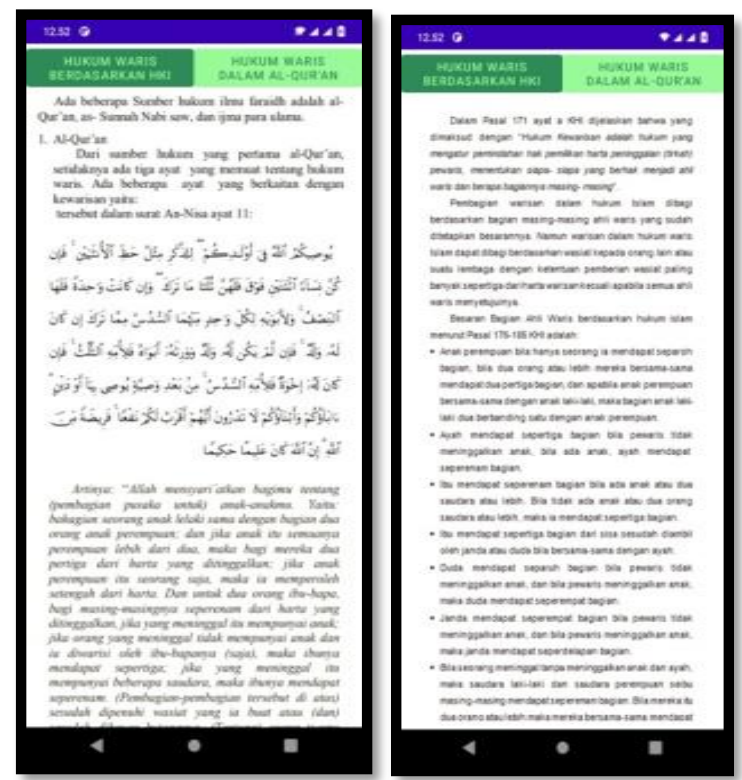

Gambar 6. Tampilan menu hukum waris

Pada tampilan ini terdapat referansi dallil yang berkaitan dengan faraid yang mana dalil tersebut dipetik dalil hadits shahih seperti hadits riwayat Abu Dawud, hadits riwayat Ibnu Majah, dan hadits riwayat Ad Darimi. Tujuan disertakan dalil ini adalah untuk memperkuat pemahaman tentang pentingnya memahami ilmu faraid. Dalam menu dalil waris ini terdapat 3 hadits mengenai faraid. Pengguna harus menscrollnya kebawah jika ingin melihat dalil tersebut secara keseluruhan.

\section{7) Menu Tentang}

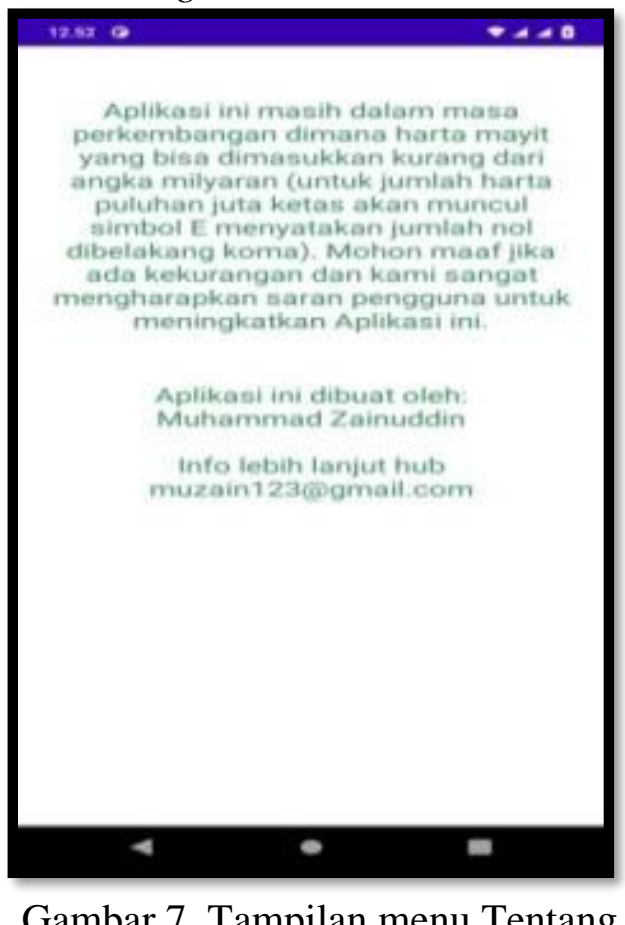

Pada tampilan ini terdapat sekapur sirih dari penulis atau pembuat aplikasi.

Pada menu ini digambarkan pada gambar 4.8 user akan ditanyakan lagi apakah yakin ingin keluar dari aplikasi atau tidak. Jika sudah yakin ingin keluar maka pengguna dapat menekan tombol "Ya" yang ada dilayar monitor namun jika ingin keluar dari aplikasi ini maka pengguna dapat menekan tombol "tidak" pada layar monitor.

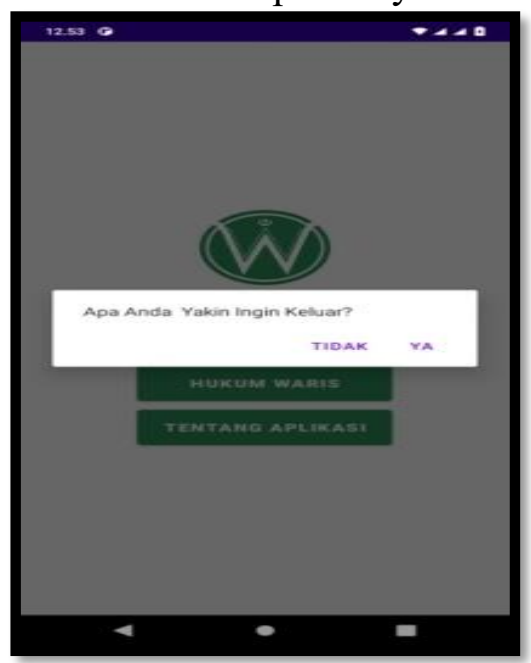

Gambar 8. Tampilan menu keluar. 


\section{KESIMPULAN}

Setelah merancang dan menyelesaikan Skripsi ini, maka penulis menarik beberapa kesimpulan antara lain :

a. Aplikasi sistem pakar ini berfungsi sebagai referensi tentang bagaimana cara pembagian waris menurut syari'at Islam sesuai dengan kasus yang ada. Sistem pakar ini juga akan menampilkan dasardasar hukum yang mendasari pembagian waris tersebut.

b. Dalam Aplikasi ini, dijelaskan juga Materi-materi yang berhubungan dengan Ilmu waris, sehingga siapapun bisa mempelajari lebih jauh tentang waris dalam Islam.

\section{UCAPANN TERIMA KASIH}

Alhamdulillah, Puji syukur kehadirat Allah SWT yang memeberikan rahmat dan anugerah-Nya sehingga penelitian ini bisa terselesaikan. Dalam penelitian ini, penulis menyadari bahwa masih banyak kekurangan dalam penelitian ini, maka 'penulis mengharapkan kritik dan saran, sehingga penelitian ini dapat disempurnakan. Semoga penelitian ini dapat bermanfaat bagi peulis, pembaca, dan dapat memperkaya khazanah ilmu pengetahuan

\section{DAFTAR PUSTAKA}

[1] (2013). Website Resmi Pemerintah Kabupaten Agam tentang "Warisan". Agamkab.go.id. https://www.agamkab.go.id/Agamkab/detailkarya/478/ warisan.html

[2] $\longrightarrow$ Instruksi Presiden Republik Indonesia Nomor :1 Tahun 1991 tertanggal 10 Juni 1991 tentang "Penyebar Luasan Kompilasi Hukum Islam".

[3] Adhuri, D. \& Aziz, A. (2015). Aplikasi Sistem Pendukung Keputusan Perhitungan Waris Berbasis Web. Jurnal Ilmu Komputer, 2012; 8(1): 32-39.

[4] Ali ash-Shabuni, M. (2015). Pembagian Waris Menurut Islam, Jakarta. Gema Insani Press.

[5] Amin, N. (2020). Tabel Ahli Waris dan Bagian Waris Hukum Waris Islam Indonesia Menurut Kompilasi Hukum Islam. https://www.hukumit.com/2013/10/tabel-ahli-warisdan-bagianwaris.html. (Kamis, 02 April 2020)

[6] Arifin, B. Pelembagaan Hukum Islam di Indonesia, Akar Sejarah Hambatan dan Prospeknya. Jakarta: Gema Insani Press. 1996 (49).
[7] Fery, M. (2014). Tinjauan Hukum Pewarisan Bagi Anak Sepersusuan Dihubungkan Dengan UndangUndang Nomor 1 Tahun 1974 Dan Hukum Islam. Unpad.ac.id.

https://doi.org/http://repository.unpad.ac.id/frontdoor/in dex/index/docId/132191

[8] Habiburrahman, Irfan. (2008). SISTEM PAKAR WARIS BERBASIS WEB. Jurnal Teknik Informatika.

[9] Hakim, Marwan. (2020). Sistem Pakar Mengidentifikasi Penyakit Alat Reproduksi Manusia Menggunakan Metode Forward Chaining. TEKNIMEDIA: Teknologi Informasi Dan Multimedia,1(1), 59-67.

Doi : https://doi.org/10.46764/teknimedia.v1i1.16

[10] Handojo, Andreas. (2001). Perencanaan dan Pembuatan Sistem Pakar Untuk Spesifikasi jenis Anjing. JURNAL INFORMATIKA Vol 2, NO. 2, November2001: 72-78.

[11] Ikhsanto, Ridho \& Migunani. (2015). APLIKASI PEMBAGIAN HARTA WARIS DALAM ISLAM BERBASIS ANDROID. Jurnal Teknologi Informasi dan Komunikasi, ISSN:2087-0868, Volume 6 Nomor 1 Maret 2015.

[12] Karsayuda, Rifqinizamy M. (2006). Menakar NilaiNilai Keadilan Kompilasi Hukum Islam. Yogyakarta. Total Media.

[13] Natarsyah, Syahib. Saniah. (2020). MODEL APLIKASI PEMBAGIAN HARTA WARISAN BERDASARKAN KOMPILASI HUKUM ISLAM BERBASIS WEB. Jurnal Ilmiah Teknik Informatika dan Sistem Informasi, Vol. 9, No. 3, Desember 2020: 181-192.

[14] Nirsal. (2015). Sistem Informasi Pengelolaan Data Pembagian Harta Warisan Menurut Hukum Islam pada Pengadilan Agama Kota Palopo. Jurnal Ilmiah Information Technology d'ComPutarE, 2015; 1(2): 26 35 .

[15] Ongko, fendhy. (2004). Perencanaan dan Pembuatan Aplikasi Sistem Pakar Untuk Permasalahan Tindak Pidana Terhadap harta Kekayaan. JURNAL INFORMATIKA Vol. 5, No.1, Mei 2004 : 32-38.

[16] Puspita, H. (2011). Aplikasi Pembagian Warisan Menurut Kitab Undang-Undang Hukum Perdata (Hukum Waris Barat). Skripsi, Banjarbaru: Sekolah Tinggi Manajemen Informatika dan Komputer (STMIK) Banjarbaru.

[17] Roji, F. F., Satria, E., \& Tresnawati, D. (2015). Pengembangan Aplikasi Pembagian Harta Waris Islam Berbasis android. Sekolah Tinggi Teknologi Garut.

[18] Setiawan, R., Destiani, D., \& Slamet. (2012). Perancangan Sistem Pakar Untuk Pembagian Waris Menurut Hukum Islam berbasiskan web. 
TEKNIMEDIA - Volume 2, Nomor 2, Desember 2021: 104 - 111

https://jurnal.sttgarut.ac.id/index.php/ algoritma/article/view/2.

[19] Setyawan, S. A. (2016). Tinjauan Yuridis Terhadap Pembagian Harta Waris Kepada Ahli Waris Yang Beda Agama Melalui Wasiat Wajibah. Fakultas Hukum Universitas Muhammadiyah Surakarta

[20] Sugiyono. (2017). Metode Penelitian Kuantitatif, Kualitatif, dan R\&D. Bandung :

Alfabeta, CV.

[21] Tiara, \& Novrina. (2016). Aplikasi Sistem Pakar Faraidh Berbasis Web Menggunakan Metode Forward Chaining. Jurnal Informatika dan Komputer, 2016; 21(3): $27-36$. 